Names, 33, No. 3, September, 1985

\title{
On Homonymy between Proper Name and Appellative
}

\section{VIBEKE DALBERG}

The terms "appellatival name" or "(semi-)appellatival name" occasionally occur in discussions of Scandinavian place-names. They are used of place-names which in their function as proper names correspond to words current in the appellatival vocabulary. The place-names which have been called "appellatival" or "(semi-)appellatival" thus have counterparts which are not proper names. The terms are particularly frequently employed of place-names whose counterparts are topographical appellatives. Examples are place-names such as Bakken, which corresponds to the definite form of the appellative bak "brook" (bakken "the brook"), and Kalvehaven, which corresponds to the appellative kalvehaven ("the enclosure for calves"). The so-called "appellatival" or "(semi-)appellatival" place-names have sometimes been drawn into the discussion about the demarcation between the proper name and the appellative. Proponents of the fairly commonly advocated theory that the line of demarcation between proper names and appellatives is fluid have thus pointed to the very existence of such names as evidence that it is impossible to draw a sharp line between these two categories of substantive. The "appellatival/(semi-)appelatival" place-names are thus claimed to belong to a frontier zone between proper names and appellatives. ${ }^{1}$

My reasons for beginning a study of the semantic aspect of placenames corresponding to current appellatives with a discussion of a technical term which may be peculiar to Scandinavian and is certainly unfamiliar to many of my readers are twofold. Firstly, the Scandinavian terminology is based on a view of the semantics of the proper name which is bound to be of interest even outside the Scandinavian linguistic-area; and secondly, I find it difficult to justify the use of

1 Detailed argumentation in T. Andersson, "Om ortnamn och ortnamnsforskning," Namn ocb bygd, 61 (1973), pp. 150-158, cf. also A. Rostvik, "Om klassificering av ortnamn," Namn ocb bygd, 57, (1969) pp. 116-119. The Swedish terms are "appellativiska namn," "(halvt) appellativiska namn." 
the term "appellatival" in connection with a synchronic assessment of place-names.

Toponyms such as Bakken, Kalvehaven and many others in the nomenclature of Scandinavia have, then, been considered to have semantic qualities different from those of toponyms such as Hven and Skagen, which do not have appellatival equivalents in the modern language. The difference between the two types of place-name has been thought to arise from the question of appellatival meaning. In a discussion of the definition of the proper name and the demarcation between proper name and appellative, the Swedish scholar Thorsten Andersson, writing of such "(semi-)appellatival" names, queries whether "it can be claimed that proper names generally lack appelatival meaning." 2 It seems, however, to be a pre-condition for labelling a place-name as "(semi-)appellatival" not only that it has a formal counterpart in a current appellative but also that the meaning of this appellative is appropriate to the locality that bears the name. The Swedish place-name Kalvhagen is thus treated by Thorsten Andersson as a "(semi-)appellatival" name if the locality that bears the name is, in fact, an enclosure for calves. In contrast, the name Lund, for example, which is identical in form with the familiar appellative lund "grove," is not considered to be "(semi-)appellatival" because it denotes not a grove but a city. The "(semi-)appellatival" names are thus taken to be descriptive of locality, characterizing. Thorsten Andersson is, in fact, in agreement with the view put forward by Wolfgang Fleischer that the relationship between proper names and appellatives is to be understood as a tension between two poles, in which the "characterizing" names lie nearest to the appellative pole. ${ }^{3}$ Both scholars, however, emphasize that the "characterizing," "appellatival" element in names is without any influence on the function of the proper names as such. This is stated by Thorsten Andersson as follows: “...for the identifying function of the name the appellatival meaning of the nameelements is irrelevant. Equally incontrovertible, however, is the fact that such meaning may well be present in names such as Kalvhagen... ",4

2 T. Andersson op. cit., p. 154 “Om man kan hävda att egennamn generellt saknar appellativisk betydelse."

3 "Zum Verhăltnis von Name und Appellativum im Deutschen," Wissenschaft liche Zeitschrift der Karl-Marx-Universität Leipzig. Gesellschafts- und Sprachwissenschaftliche Reibe, 13 (1964), pp. 369-378.

4 T.Andersson, op. cit., p. 154 “...för namnets (identifierande) funktion är namnelementens appellativiska betydelse irrelevant. Like ovedersägligt är emellertid att denna betydelse kan vara levande i namn som Kalvbagen...." 
I hasten to point out that I am not unwilling to accept that the appellative in the language in question might influence the performer. I shall go into this matter in more detail below. In my opinion, however, it can be misleading to speak about appellatival meaning in this context. ${ }^{5}$

A first and important prerequisite for the understanding of the semantics of the proper name is that diachronic and synchronic viewpoints must be kept apart from each other. The name must be assessed in its function as a proper name and such an assessment must not be confused with an assessment of the etymological components of the name. A place-name such as Kalvehaven is etymologically identical with the appellative kalvehaven "enclosure for calves" in definite form and it must be assumed that, at the time when the name was coined, this word was selected as being descriptive of the locality which came to bear the proper name Kalvehaven. At this stage there could be talk of appellatival meaning, if by this is understood-as is generally the case in linguistic studies - that the appellative indicates a quality of its denotatum (its referent) and at the same time assigns the latter to a class of objects linked by shared characteristics, in the case in question by the property of being an enclosure for calves. If the assessment is only concerned with the etymology of the name, then it is correct to use the term appellatival meaning; but the classifying properties of the appellative kalvehaven cannot, however, be transmitted further once the word has achieved the status of the proper name, irrespective of whether or not there is still homonymy between the appellative kalvehaven and the proper name Kalvehaven. This is because the function of a proper name is incompatible with the possession of classifying meaning.

The acquisition by a word of the function of a proper name means that it has been given the linguistic task of referring to one, in principle uniquely occurring, object, and conventionally that it can only be used to refer to this one object. The proper name is mono-referential. Unlike the appellative, the proper name is inherently definite, i.e. its definiteness belongs to the sphere of linguistic competence (la langue) and not to that of performance (la parole). If it had been indefinite, it would not have been able to perform its task as a proper name, i.e. of pointing to one and only one individual. This is because indefinitevereniging voor naamkunde te Leuven en de commissie voor naamkunde te Amsterdam, 41 (1965), pp. 10-12. 
ness implies the existence of more than one individual of the same kind about which the word can also be employed. It is this inherent characteristic which receives grammatical expression in the well-known neutrality of the proper name in respect of the grammatical categories of definiteness and number. In connection with proper names the definite inflexion does not have its normal grammatical function. A proper name may have a morpheme of definiteness, as Kalvehaven, or it may be without one as, for example, Lund, but the proper name does not show a continual circumstantially determined alternation between definite and indefinite form in the way that an appellative does. Correspondingly, the proper name is indifferent to the opposition singular:plural, since as already mentioned, it points to one and only one individual. It is true that proper names occur in plural form, as, for example, Farererne (The Faroes), Pyrencerne (the Pyrenees), but even in these cases the denotatum named is considered as a unit, as also shown by the fact that no denotatum exists for a singular form Pyrenæ, Faro. ${ }^{6}$

The appellative is indefinite in the sphere of linguistic competence, although it can be definite in performance. Therefore, it can be used of an object possessing the characteristics shared by the class, wherever this object might occur. This is not the case with proper names. The place-name Kalvehaven can only be used to refer to one particular locality, not to every locality that fulfills the condition of being an enclosure for calves. The proper name, as already mentioned, does not indicate any characteristic about its denotatum. ${ }^{7}$ This fact is reflected in another circumstance. If proper names had been characterizing, then, for example, the place-name Fiskebcek could only be the name of a fiskebæk "brook where fishing takes place" and not, as is actually the case, the name of a farm. Egeskov could only be the name of an egeskov "wood of oak-trees" and not the name of a manor. The name Tingsted could only be borne by a tingsted "place where a legal court is held" and not by a village. The place-names such as Fiskebak, Egeskov, and Tingsted are actually found as the names of a farm, a manor and a village respectively reveals, however, that it is

6

As has often been pointed out, plural forms in sentences such as "There are several Lyngbys in Denmark" and "we have three Lises in the class" do not stand in opposition to singular Lyngby and Lise but to singular a Lyngby and a Lise. The meaning, then, is "towns called Lyngby" and "girls called Lise" respectively. 7 Cf. K. Zilliacus, Ortnamnen $i$ Houtskär (Helsingfors: Svenska Litteratursallskapet i Finland, 1966), p. 41. 
of no significance for the function of the proper name that the "lexical meaning" can be considered to give misleading information about the characteristics of the locality.

Now, as mentioned above, the term "(semi-)appellatival" name would seem to be used particularly frequently of names in which there is no such discrepancy as regards the characteristics of the locality in question. Kalvehaven was thus considered to be a "(semi-)appellatival" name as long as its denotatum was, in fact, an enclosure for calves. It is, however, difficult to justify such a distinction. ${ }^{8}$ Applied to personal names this view would imply that a surname such as Flemming would have to be looked upon as "(semi-)appellatival" in cases where it is borne by a person of Flemish origin but not in cases where it is borne by a person of English origin. It should be noted here that from the synchronic point of view it is irrelevant whether Flemming, in the same way as Kalvehaven, was descriptive when it was first chosen as a name, or whether it was already in existence as a proper name when it was given to the person in question. Agreement with the characteristics of the denotatum is not an argument for ascribing total or "(semi-)appellatival" meaning to proper names, since such an agreement makes no difference to the fact that in principle the proper name is without appellatival characteristics.

From a synchronic point of view neither the term "appellatival" nor the superficially more nuanced term "(semi-)appellatival" can be claimed to be an adequate description of any proper name. Place-names such as Kalvehaven cannot, therefore, be used as evidence in support of the theory that the boundary between the categories proper name and appellative is fluid. It is a different matter altogether, of course, that in the concrete performance situation it can be extremely difficult to decide whether a particular linguistic item is a proper name or an appellative, i.e. whether there is talk of, for example, a place-name Kalvehaven or an appellative in definite form denoting a locality, kalvehaven "the enclosure for calves." The performers can, in fact, use both words of one and the same locality. The problem can often become embarrassing, when a toponymist has to decide which linguistic items are to be included in his survey and which are to be left out. The difficulty can occur with both oral and written material, with both contemporary and historical sources. Just because there is no way of determining the correct categorical

$8 \quad$ Cf. G. Albøge, "Om stednavnets begreb og structur," Acta Pbilologica Scandinavica, 31,2 (1976), p. 145. 
affiliation of the word, however, this does not justify us in taking it to be a transitional form between an appellative and a proper name nor in using it as the basis for the establishment of a boundary-zone in which the word can be placed.

From a synchronic point of view the connection between the proper name and appellatival vocabulary and meaning must, in my opinion, be restricted to the determination of the fact that there can be formal identity between the proper name and an appellatival word. This is not, however, to say that such identity-which will henceforward be referred to as homonymy ${ }^{9}$-is without interest for a discussion of the semantics of the proper name.

In the course of time, widely diverging opinions have been expressed as to the meaning of the "proper" name. Some scholars have denied that the proper name has any meaning at all, while others, on the contrary, have claimed that their meaning-content is exceptionally large. ${ }^{10}$ The disagreement would seem to arise first and foremost from a difference in the definition of the concept of meaning.

As has been pointed out above, proper names lack classifying, characterising meaning and it is this lack which has given rise to the claim that they are without meaning. It leads, however, to a much too restricted description of the semantic structure of the proper name, if the focus is placed on this aspect alone, notwithstanding that it is in this aspect that the essential difference in relation to appellatives is to be found. A number of more recent discussions of the semantics of the proper name have operated with various types of meaning. ${ }^{11}$ In my opinion these views have been expressed most clearly by W. van

9 In the present article the term embraces both homophony and homography and is employed of these phenomena irrespective of whether or not the words in question are of different etymological origin.

10 John Stuart Mill (e.g. A System of Logic, Ratiocinative and Inductive, $10 \mathrm{I}$ (1879), p. 36), and Otto Jespersen (e.g. The Pbilosopby of Grammar (1924), p. 66) are often cited as extremist representatives of the two contrasting points of view.

11 Inter alia B. Pamp, "Vad betyder G"osta Holm engentligen?" Nordiska studier $i$ filologi ocb lingvistik (Lund: Studentlitteratur, 1976), pp. 330-342; F. Debus, "Aspekte zum Verhaltnis Name-Wort," Probleme der Namenforscbung im deutschsprachigen Raum, Herausgegeben von Hugo Steger (Darmstadt: Wissenschaftliche Buchgesellschaft, 1977), pp. 3-26; B. Pamp, "Egennamn och betydelse av betydelse," Namn ocb bygd 67 (1979), pp. 56-65; W. van Langendonck, "Paradoxen van de eigennaam," Naamkunde, 11 (1979), pp. 181-196. 
Langendonck who, starting with Leech's semantic model, ${ }^{12}$ distinguishes between conceptual meaning and associative or pragmatic meaning. Taking as illustration one of the favorite examples of the semanticists, bachelor, it can be said that the meaning "unmarried man" belongs to the conceptual meaning, while meanings such as "lonely wretch," "egoist," "free agent" are associative. This latter type of meaning, the associative one, ${ }^{13}$ can be found in proper names as well as in appellatives-indeed, the proper name is often more abundantly provided with such meanings than is the appellative. This may be explained as a result of the mono-referential character of the proper name. More opportunities arise for associative meaning in connection with a word which is only used of one particular object than in connection with a word which can in principle be used of an infinite number of specimens. It is thus with reference to the presence of associative meaning in the proper name that the latter can be said to have a richer meaning-content than the appellative.

In this connection it should be mentioned that the term connotation/connotative meaning is employed in the specialist literature of each of the two aspects of meaning that have been described here. ${ }^{14}$ This fact has not, of course, contributed to the clarity of the discussion. In Scandinavian onomastic studies the term connotation is generally used of exactly that type of meaning that a proper name cannot possess. As, for example, in the following quotation: "...the names cannot be assumed to have connotative meaning in the same way which such a meaning is ascribed to appellatival expressions. It is in the nature of connotation that it forms a definition of that class of objects or the like which an expression can denote."15 Associative meaning is thus often referred to by Scandinavian scholars as secondary/connotation. ${ }^{16}$ It is mainly outside of Scandinavia that the term connotation is used particularly of associative meaning; for example, in the

G. Leech, Semantics (Harmondsworth, Middlesex: Penguin Books Ltd., 1974).

13 The term "associative" is used in a rather different sense by W.F.H. Nicolaisen (see for example "Names as Verbal Icons," Names, 22 (1974), p. 104). 14 Cf. J. Algeo, On defining the Proper Name (Gainesville: University of Florida Press, 1973), p. 64.

15 K. Zilliacus, op. cit., p. 40, 41, “...namnen (kan) inte tillerkännas konnotative betydelse i samma mening som en sådan tillskrivs de appellativiska uttrycken. Det ligger i konnotationens natur, att den utgör en definition av den klass av föremål el.d. som ett uttryck kan denotera."

16 E.g.K. Zilliacus, op. cit., p. 40. 
following quotation: “Das norw. Appellativum eng 'Wiese' enthalt fur einen Sprecher/Horer vielleicht die Konnotation von saftigem Grun und Gänseblümchen; bei Nennung des Familiennamens Eng/schwingen eventuell Erinnerungen an einen Bekannten dieses Namens mit."17

By the term associative meaning, as I choose to call it, is meant (secondary) meaning(s) which can be ascribed to words as a result of the individual performer's experiences with, and opinions about, the object referred to. Associative meaning can be further divided into several subcategories of meaning but I do not intend to go into this matter here except just to mention that in principle these meanings are all subjective and can, therefore, vary from performer to performer, although some of the meanings would seem to be shared by most speakers who have the same cultural and linguistic background. ${ }^{18}$ Further, homonymy can promote associative meaning in that the meaning of one word can contaminate, so to speak, that of another. There are many examples of this happening when proper names are homonymous with appellatives. The clearest manifestation of such an associative meaning occurs in cases in which the homonymous appellative bestows upon the proper name a meaning which seems to the performers to be so unpleasant that they wish to do away with the proper name and replace it with another one. The reason, for example, that the Danish village-names Rumperup and Gumperup had to be replaced by other names at the insistent request of the inhabitants in the 1920 's, was that people were embarrassed by the homonymy between the specifics of the names and the appellatives rumpe and gump, two rather vulgar words for "backside." Similarly, the streetname Roven, homonymous with roven "the backside," has been replaced by another name.

Whether such homonymy has always been present or whether it is a secondary development is, however, irrelevant in the present context because the effect on the performer is the same in both cases. This can be illustrated by two more examples from Danish placenames: the village-name Brøndsted is etymologically a compound of the appellative brond "spring" and the appellative sted "place;" the village-name Kongsted, on the other hand, can be analyzed as containing Kongs-, the genitive singular of the appellative konge "king"

17 K. Hilgemann, Die Semantik der Eigennamen (Göppingen: Verlag Alfred Kummerle, 1978), p. 33.

18 W. v. Langendonck, op. cit., p. 181, 185, 187. 
and -ted, which is a development from the Old Danish appellative thwēt "clearing." For the modern performer, however, both names share homonymy with the familiar appellative sted "place."

Another characteristic of associative meaning is, as mentioned above, that it is subjective and unsystematic in occurrence. This can also be illustrated by changes of name resulting from homonymy. The homonymy which gives rise to a change of one name may be perfectly acceptable in another name. Thus there are many Danish placenames which show homonymy with the appellative tyv "thief" but while this does not seem to have bothered the inhabitants in the majority of instances, in other cases it has clearly been felt to be embarrassing. One of these latter instances provides a good illustration of the subjective nature of associative meaning. At the end of the 16 th century the village-name Tyvkar was changed to Fredskaer by command from the highest quarters, namely the king himself. Although a heavy fine was imposed upon those who went on using the old name, the locality continued to be known as Tyvkar. The homonymy did not irritate the local population in the same way as it had done the king; A couple of hundred years later, however, the situation had changed. When the spelling of the name was taken up for revision in the 1930's, the local authority recommended that an old spelling (Tiufkar) should be revived so that homonymy with the appellative tyv "thief" could be avoided. This altered spelling was in fact authorized and Tiufker is the official form of the name today.

I should like to conclude by suggesting that proper names of the type Kalvehaven, Bakken, etc., should be looked at from the same point of view. These so-called "transparent," "understandable" names are generally employed without any apparent awareness on the part of the performers that they correspond to familiar, current appellatives in the language. ${ }^{19}$ If the names-as must undoubtedly sometimes be the case-transmit information to the user about an "enclosure for calves," a "brook," should this then be looked upon as a manifestation of homonymy with the appellatives kalvehave, bæk, etc.? Or to put it in other words, would it not be more satisfactory to refer to the type of meaning which some scholars have called "(semi-)appellatival" as associative meaning?

University of Copenhagen (Denmark) 